\title{
The rate of high schools' graduating students to universities
}

\author{
Luminiţa Claudia CORBU \\ Ştefan cel Mare University, Suceava, Romania \\ Daniela Mihaela NEAMŢU \\ Ştefan cel Mare University, Suceava, Romania \\ Valentin Cristian HAPENCIUC \\ Ştefan cel Mare University, Suceava, Romania \\ luminitaclaudia@yahoo.com
}

\begin{abstract}
The purpose of the present research is to analyze and explore the opinions of Fălticeni town high school graduates, on the choice of universities that they want to continue their studies, then choosing faculty (profile, specialization) where they will be trained for their future profession. Then first thing taken into account was the ratio of students admitted in the first year of higher education studies in a given academic year, expressed as a ratio of the number of students enrolled in the final year of upper secondary education in the previous school year. For the indicator highlighted and previously enunciated, we conducted a statistical survey based on the data collected from three high schools in Fălticeni town, from Suceava County, schools with different specializations and different profiles of study. In recent years, countries have increased the diversity of education programs. This diversification has been driven by an increasing demand for upper secondary and evolving curriculum of general knowledge taught in general programs and practical skills reserved for professional studies to complete programs that include learning, but also to lead to more flexible ways of further education or employment.
\end{abstract}

Keywords: rate of transition, levels of education, higher education, education program, education system in European Union.

\section{Introduction}

In a modern society, education plays an important role, becoming increasingly a major source of competitiveness in the markets. The qualifications that the educational institutions provide depend on the value of their products, fact in a directly and essentially way which will be clearly seen at the future generations of specialists, being a benefit to society. Worldwide there is currently a prerequisite that the education systems must begin, continue and support. Thus, the transformations and the social progress, providing quality education, preparing the individual for the future and at the same time developing its capabilities to adapt to technical and scientific change and to create new things are considered an inner performance. Ultimately, the educational institutions do not only transmit knowledge but they also produce or apply new technologies. Today, when knowledge is the most important commodity, and the school is an institution of knowledge, the implication is obvious. The findings on the correlation between the level of education development and economic and social progress in different countries have convinced governments of the need to improve the sector as a prerequisite for ensuring an economic prosperity and a higher level of civilization and the standard of living of the people. 
Therefore, at present, it is a fact that in all countries there is a constant concern for better organization and development of the public education, free of charge or at reduced fees or to support the private subsidies, which involves increased public expenditure for that sector.

In the previous years, it is noticeable that many governments concern education among national priorities in increasing measure, which means it has become a force with particularly strong idea that a better education and a more efficient public school is essential for the economic development of the state. Moreover, the faith in the virtues of education is so high that, although there are many criticisms of its governments not looking too willing to cultivate the concept of informal education for the benefit of formal, emphasizing instead the necessity of modernization of education, to increase the efficiency by improving quality.

\section{Literature review}

The contribution of higher education to economic growth involves an interaction of several factors. First, it is believed that higher education contributes to economic growth by "production of knowledge, research". This highlights taking place in universities through research and creative activity. Secondly, it is recognized that universities and colleges contribute to national economic growth by "dissemination of knowledge", resulting in to a positive feedback thereof. Lastly, it is universally accepted that higher education contributes to "transfer of knowledge" through extensive and varied teaching activities. The economists focused on these activities, measurable by registration, completed postsecondary education, the number of graduates, the degree of graduation expenses and income students (Becker and Lewis, 2003).

Everywhere higher education was considered to be a key to the growth and development of national economies (George, 2006). But the role of higher education is not limited to promote economic development of the states and to provide different opportunities for each individual, but it extends to the promotion of cultural, commercial and political democracy (Marginson, 2010). Higher education and knowledge, which it produces, generates significantly local, regional and global levels of education.

Krueger and Lindahl (2001) believed that education is the key to an economic growth of a nation. In this regard, our opinion is that the differences between the developed and the developing world are due to largely education of the members of these countries, and Mankiw, Romer and Weil (1992) reinforce this view, considering that education is the key in explaining the economic growth of different countries.

Recent evidence suggests that higher education is both a result and a determinant of the income, but it can produce public and private benefits. Higher education can increase tax revenues, increase savings and investments and may lead to a company with a civic and entrepreneurial spirit. It can also help the improvement of the health system of a nation, the technology development and the strengthening governance.

The access to education, especially higher education is often hampered by high costs involved. The consumers education are calculating efficiency before deciding on their investment in their training because each individual follows his certain needs or desires to improve his condition, to evolve and to achieve a certain threshold of a personal development, when he decides to do something for his own education (Symanski and Henard, 2001). 
According to Cojocaru and Făuraş (2006), the decision to invest in their own education is based on the welfare of the individuals - which is actually a unique set of finality that can be attained by the goods supplied by the economic and educational system. The investment will engage not only the bearer of the human capital, but it also engages the entire society, a society that will benefit from increased labor supply and the number of citizens with a high level of education, being called externalities. In this context, we mention Friedman's (cited in Cojocaru and Făuraş) conclusions: "a stable and democratic society is impossible without widespread acceptance of a common set of values and without a minimum degree of literacy and knowledge of most citizens. The benefits of education on a child will be reflected not only the child or his parents, but also to other members of society ... promoting a stable, democratic society." However, that implies learning to thing in the long run and to create strategies for the unpredictable future (Bolisani and Bratianu, 2017; Bratianu, 2007).

\section{The research methodology}

The method approached in the present research is quantitative. The collecting of data has been done through a survey which was elaborated and applied to the students from the $12^{\text {th }}$ grade of two high schools from the country Suceava, in a period of time of two years, 20132014 and 2014-2015. The technique of random sampling and adequate stratification was used for questioning both genres. The research was performed by elaborating and organizing a survey among high school students to continue their studies at a university level in Romania.

The value conferred by the results of the research will be benefic to the application of a strategy in high schools with the aim of improving the percent of teenagers enrolling the university system. The results of the study could determine the management of high schools to give a greater importance to the training of young adults and to identify programs and efficient methods of studying centered on the student which can lead to the increase of their performance.

The purpose of this work is to evaluate the importance given to secondary education, of investment and professional training and their effect on their performance through the continuation of studies at a higher level.

Our study aims to offer information's which can help the substantiation of choosing a variant of action, depending on certain decisional criteria in the education field. It is important for the decision makers in the education field to identify the situation which can lead to real problems, but also favorable occasions which should be harnessed.

In the literature there are diverse studies which analyze the efficiency of educational systems, referring especially to the results of the professional career of the graduates on the labor market. The main motivation regarding the correlation of the schooling plans with the necessities of the labor market consists in the economic and social development as a source of improvement for the standard of living at the level of the whole society. Following the logic of the professional route of the graduate, with the aim of collecting empirical data, it was used a survey of which questions were structured on two main themes: the graduated studying program; the specializations the graduate wishes to follow; socio-demographic data. 


\section{Determining the size of the sample}

For determining the size of the sample, we use the following formula:

$$
n=t^{2 *} p^{*}(1-p) / e^{2}
$$

where:

PICBE| 287

$\mathrm{n}=$ the size of the sample;

$t=$ the theoretical value of the acceptance probability (we have used $t=1,61$ for a level of trust of $90 \%$ );

$\mathrm{p}=$ the precent in which the population has the sampling feature (usually 0,50 );

$\mathrm{e}=$ the limit error of reprezentativeness admitted (between $1 \%$ and $5 \%$ at highest).

This way, in the care of this research, for a maximum admitted error of $5 \%$ and trust level of $95 \%$, the calculation is the following:

$$
\mathrm{n}=\left(1,606^{2} * 0,5 *(1-0,5)\right) / 0,05^{2}=258
$$

To find out the students opinions regarding the choice of continuing with another form of preparation, we innvestigate the openions of 258 people.

\section{Processing, analyzing and interpreting information}

For evaluating the education system as a whole, in a holistic approach to education and training specific to the European Union, the National System Indicator identifies a number of key indicators necessary for establishing the quality of education, which is listed and the transition rate level higher education. It is the ratio of the number of students admitted in the first year of higher education studies in a given academic year, expressed as a ratio of the number of students enrolled in the final year of upper secondary education in the previous school year.

To illustrate with certain data, the indicator set with actual values and its use in evaluating the education system there are some examples taken from the databases of two Colleges in Fălticeni. The two colleges are the National College "Nicu Gane", theoretical profile and Technical College "Mihai Băcescu", technical profile. The examples given refer to upper secondary education and transition to the next level, that of higher education, including data from 2013 until 2014, 2015 and 2016. It is important to note the insertion path of the student to the next level of education after completing the upper secondary education. For example, at the National College "Nicu Gane", most students attend some form of higher education, reaching 97\%, which cannot be AFIM in the case of the latter institution, whose value percentage approaching 50\% in 2015. As for the years 2013 and 2014, Technical College "Mihai Băcescu" recorded much lower, 15\% and 21.14\%. In case of the National College "Nicu Gane", it retains the same value percentage for the other two reporting years 2013 and 2014.

\section{Choosing the field of study}

The areas of study followed by students are various, an influence of the profile has completed upper secondary level. In figure no. 1, for 2015, with a total of 258 students, the 
National College "Nicu Gane", presents the following statistical rate of transition from secondary education to university level:

- 30\% of the number of students heading for the medical field.

$-27 \%$ will graduate humanities.

- 24\% real field as: Mechanics, Telecommunications, Electrical etc.

- A small percentage, $1 \%$ occupy areas as: Textile, Physical Education and Architecture.

- About $1 \%$ are universities abroad.

- Universities preferred by students are Iasi- 37\%, 19\% Bucharest, Suceava, 9\%, 6.3\% Cluj etc.
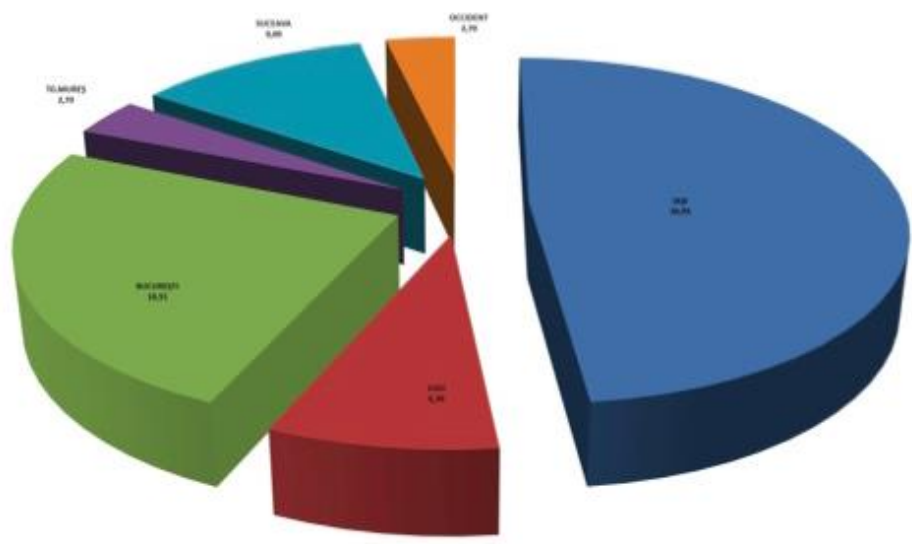

Figure 1.Universities chosen by students of real profile, in 2016

Source: Own elaboration based on data collected from the National College Nicu Gane Fălticeni annual statistical situation.



Figure 2. Universities chosen by students of human profile, in 2016

Source: Own elaboration based on data collected from the National College Nicu Gane Fălticeni annual statistical situation.

For 2016, the most chosen University center is in Iasi (47\%), followed by Bucharest (29\%), Suceava (9\%), Cluj (7\%), Târgu-Mureş (4\%) and Universities abroad (see Figure no.1, the second picture). The reason for choosing these universities are: proximity to home, quality of education, age, tradition university center etc. The situation changes for 
students who complete a human profile for the same period. From this point of view, those university centers are the most chosen: Iasi (23\%), Suceava (15\%), Cluj (12\%), Bucharest $(8 \%)$ etc.

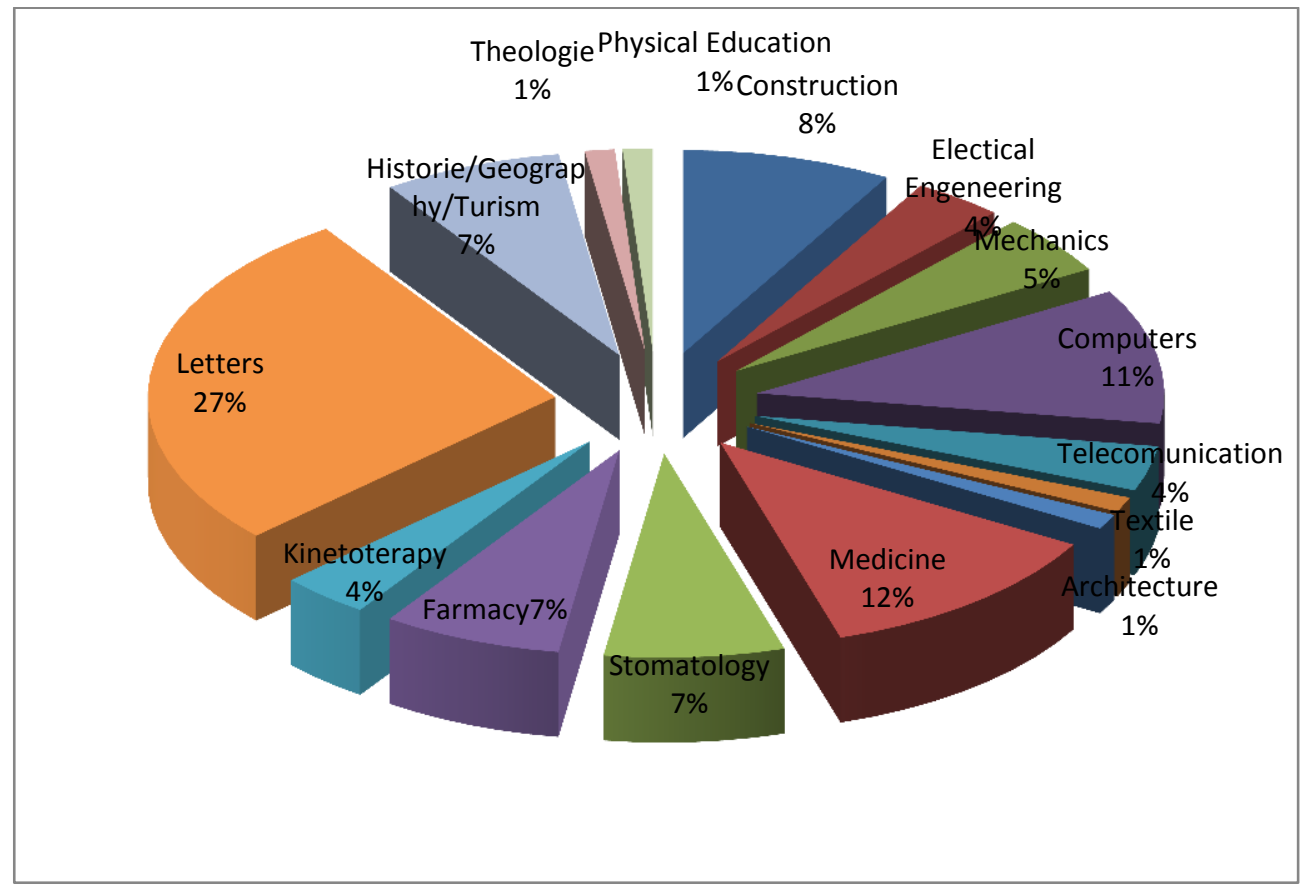

PICBE 289

Figure 3. The rate of transition to higher education level in 2015

Source: Own elaboration based on data collected from annual statistics of National College Nicu Gane Fălticeni.

The students from the Technical College "Mihai Băcescu" Falticeni have different options in choosing areas of activity. In figure no.3, in 2015 from a total of 258 graduate students, the rate of transition to the next level of education is as follows:

- $50 \%$ of students attend university

- 13\% are employed on labor market

- 2\% are natural persons authorized and operate their own business, or they are farmers

- 4\% remain jobless

- $9 \%$ choose a job abroad. 


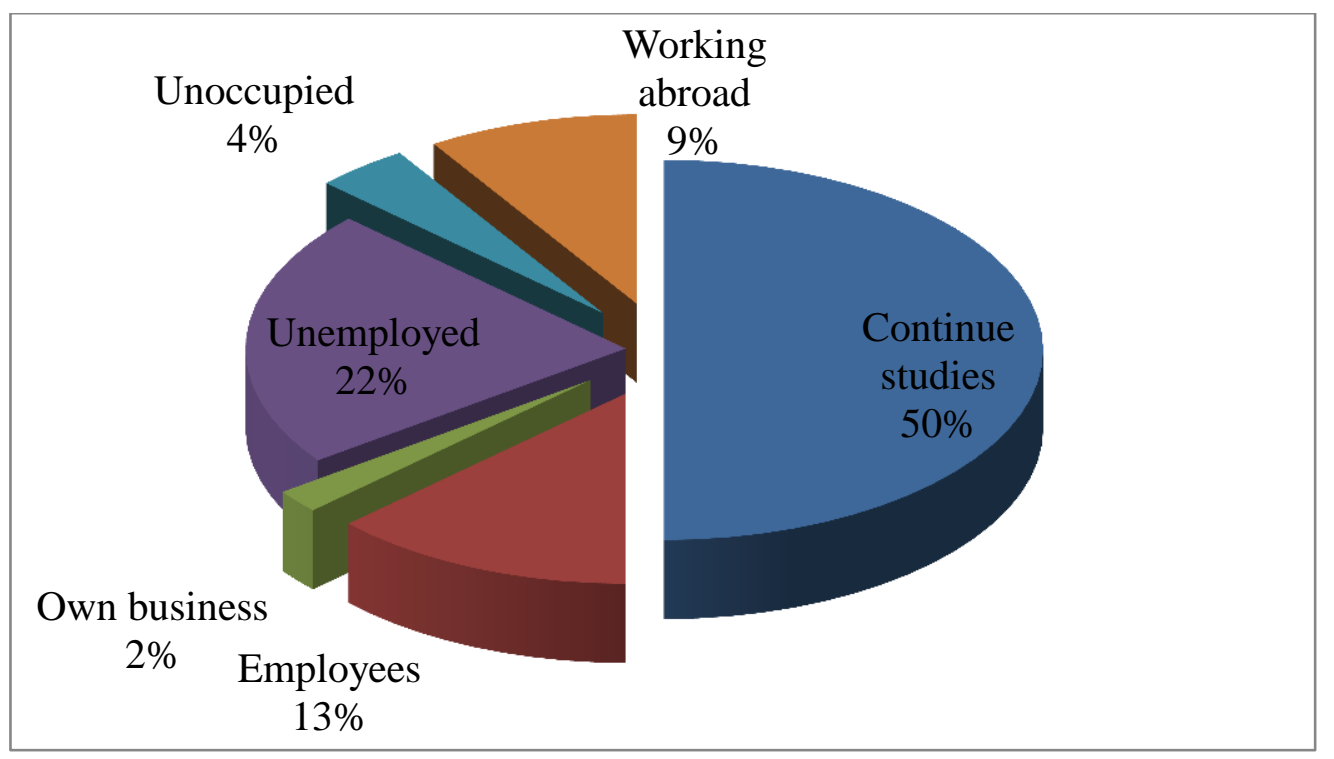

PICBE 290

Figure 4. The rate of transition to higher education level, 2015

Source: Own elaboration based on data collected from annual statistics situation of Technical College Mihai Băcescu

Fălticeni.

According of the figure no. 4 the proportion is balanced. The most of the students (50\%) of Technical College "Mihai Băcescu" are determined to pursue some form of higher education or a qualification in a particular field of education, while the other half has different options: $9 \%$ working abroad, $22 \%$ fail to find a job, $4 \%$ remain unemployed, $13 \%$ work in a state or private company and only $2 \%$ create their own business.

\section{Conclusion}

After the communist period the Romanian education system has undergone a number of major changes as follows: the multiplication of public and private institutions of higher education, the diversification of study programs, numerous legislative changes, the institutional democratization concerning the improvement of the research and the extension of the international communication etc.

The data analysis noticed a not very beneficial situation for the Romanian education system. Only $50 \%$ of students undergoing study follows a higher level of training, for which Romanian education structure will suffer in the next period recorded a number of increasingly low human resource in education.

Of all pupils interviewed, $75 \%$ follow a superior form of education. Worrying is that a high percentage $(17 \%)$ cannot pick their professional path. Noteworthy is that large academic centers remained among the favorites, for students who choose humanities and those who choose a real profile. Universities like those in Bucharest and Iasi have the highest percentages of students' preferences, followed by Cluj, Suceava and Târgu Mureș.

So that the managers can appreciate their employees at their righteous value it is necessary that they have an adequate education. The education level of a person affects the level of its earnings, existing direct proportionality between them. The higher level of studies a person has, the better the person is prepared to absorb the new information and familiarize with the new technology, this way their earnings being considerably increased. 
The education a person gets also has powerful implications on the job they are working at. Educated employees have at least two advantages against the less educated ones, which are the bigger salaries and a better stability at the work place. Since future is unknown and unpredictable, and the knowledge cycle is shortening continuously, it is important for young people to develop better models of thinking and valuable employability skills.

\section{References}

Becker, W. E. and Lewis D. R. (2003, p.3) apud Ozsoy Ceyda (2008) The Contribution of Higher Education to Economic Development, Publishing Global Conference on Business \& Economics, Italy.

Bloom, D., Canning, D. and Chan, K. (2005), Higher Education and Economic Development in Africa, Harvard University Press, Boston.

Bolisani, E. and Bratianu, C. (2017), Knowledge strategy planning: An integrated approach to manage uncertainty, turbulence, and dynamics, Journal of Knowledge Management, 21(2), 233-253.

Bratianu, C. (2007), Thinking patterns and knowledge dynamics. In Remenyi, D. (Ed.), Proceedings of the $8^{\text {th }}$ European Conference on Knowledge Management (pp. 152156), Consorci Escola Industrial, Barcelona, Spain, 6-7 September 2007. Academic Conferences and Publishing International, Reading.

Cojocaru V. and Făuraș C., (2006), Educația în abordare economică, Editura Academia de Studii Economice din Moldova, Chisinau.

Mankiw, G.N., Romer, D. and Weil, D.N. (1992), A Contribution to the empirics of economic growth, The Quarterly Journal of Economics, 107(2), MIT Press, Boston.

Marginson S. (2010), Higher Education in the Global Knowledge Economy, Procedia Social and Behavioral Science, p. 6962.

George, St. E. (2006), Positioning higher education for the knowledge based economy, Journal of Higher Education, 21(1), 15-26.

Krueger, A.B. and Lindahl, M. (2001), Education for growth: Why and for whom? Journal of Economic Literature, 39, 1101-1136.

Ministerul Educaţiei Naţionale (1998). Învăţământul superior într-o societate a învăţării, București, p.17.

Mincer, J. (1981), Human Capital and Economic Growth, (NBER), paper No. w0803.

Neculau, A. (1997). Câmpul universitar şi actorii săi, Editura Polirom, Iasi.

Otero, M.S. and McCoshan, A. (2010), Study on access to education and training, Tender no. EAC/38.04, Lot 1, Final Report for the European Commission, ch.2 - Access Education and Training in the Context of Europe 2010, ch.3, Conceptual Framework, p. 8-20.

Symanski, D. M. and Henard, D. H. (2001), Customer satisfaction: A meta- analysis of the empirical evidence, Journal of Academy of Marketing Science, 29(1), 16-35. http://davidhenard.com/Landing_Page/CV_Bio_Research_files/Szymanski\%20\%26\% 20Henard\%202001.pdf

Serdean, I. (2004), Pedagogie, Editura Fundaţia de mâine, București.

Suciu, M.C. (2000), Investiția în educație, Editura Economică, București. 